\title{
The incidence and risk factors of falls in Parkinson disease: prospective study
}

\section{Częstość występowania i czynniki ryzyka upadków w chorobie Parkinsona: badanie prospektywne}

\author{
Monika Rudzińska', Sylwia Bukowczan', Joanna Stożek², Katarzyna Zaidel ${ }^{3}$, Elżbieta Mirek², Wiesław Chwała2, \\ Magdalena Wójcik-Pędziwiatr', Krzysztof Banaszkiewicz', Andrzej Szczudlik' \\ 'Department of Neurology, Jagiellonian University Medical College, Krakow, Poland \\ 2Department of Clinical Rehabilitation, University School of Physical Education, Krakow, Poland \\ 3 Institute of Otolaryngology, Department of Otolaryngology, Jagiellonian University Medical College, Krakow, Poland
}

Neurologia i Neurochirurgia Polska 2013; 47, 5: 431-437

DOI: 10.5114/ninp.2013.38223

\begin{abstract}
Background and purpose: Although Parkinson disease (PD) patients suffer falls more frequently than other old people, only a few studies have focused on identifying the specific risk factors for falls in PD patients. The aim of this study was to assess the incidence and risk factors of falls in a prospective study in comparison to a control group.

Material and methods: One hundred patients with PD were recruited to the study along with 55 gender- and age-matched healthy controls. Both groups were examined twice; the second examination took place one year after the first one. Examination of the PD group included: medical history including falls, neurological examination, assessment of the severity of parkinsonism [Unified Parkinson's Disease Rating Scale (UPDRS), Schwab and England scale (S\&E), Hoehn and Yahr scale $(\mathrm{H} \& \mathrm{Y})$, Mini-Mental State Examination (MMSE)], Hamilton scale and quality of life scales (SF-36, EQ-5D) and Freezing of Gait Questionnaire (FOG-Q). In both groups falls were recorded over the 12 months. Frequent fallers are defined as having more than 3 falls a year. Results: Over the year falls occurred in $54 \%$ of PD patients and $18 \%$ of controls. In a prospective study $28 \%$ of PD patients fell more frequently than in retrospective analysis. Frequent fallers were found in $20 \%$ of patients and in $7 \%$ of
\end{abstract}

\section{Streszczenie}

Wstęp i cel pracy: Mimo że upadki są częstsze u chorych na chorobę Parkinsona (ChP) niż u innych starszych osób, dotąd tylko kilka prac koncentrowało się na określeniu specyficznych czynników ryzyka upadków w ChP. Celem badania była ocena częstości występowania i czynników ryzyka upadków w badaniu prospektywnym w porównaniu z grupą kontrolną. Materiał i metody: Stu chorych na $\mathrm{ChP}$ oraz 55 zdrowych osób dobranych pod względem wieku i płci zostało włączonych do badania. Obie grupy były oceniane dwukrotnie, na początku badania i po upływie roku. Ocena chorych na $\mathrm{ChP}$ obejmowała: wywiad lekarski z uwzględnieniem upadków, badanie neurologiczne, ocenę nasilenia objawów parkinsonizmu [Unified Parkinson's Disease Rating Scale (UPDRS), skalę Schwaba i Englanda (S\&E), skalę Hoehn i Yahra (H\&Y), Mini-Mental State Examination (MMSE)], skalę Hamiltona, ocenę jakości życia (SF-36, EQ-5D) oraz kwestionariusz Freezing of Gait Questionnaire (FOG-Q). W obu grupach upadki były rejestrowane prospektywnie przez 12 miesięcy. Mianem często upadających określano osoby z więcej niż 3 upadkami w roku.

Wyniki: W rocznej obserwacji upadki wystąpiły u 54\% chorych na ChP i $18 \%$ osób z grupy kontrolnej. W ocenie prospektywnej $28 \%$ chorych na ChP upadało częściej niż w ocenie retrospektywnej. Częste upadki stwierdzono u $20 \%$

Correspondence address: dr n. med. Magdalena Wóicik-Pędziwiatr, Department of Neurology, Jagiellonian University Medical College, 3 Botaniczna St, 31-503 Krakow, Poland, e-mail: stokrotka283@tlen.pl

Received: 3.08.2012; accepted: 7.01.2013 
controls. Fallers showed higher scores in UPDRS, H\&Y, S\&E, MMSE, and Hamilton scale than non-fallers. Independent risk factors for falls were: age, previously reported falls and higher score in the FOG-Q.

Conclusions: Falls in PD patients occurred three times more frequently than in controls. Independent risk factors for falls were: high score in FOG-Q, older age and presence of falls in medical history.

Key words: falls, Parkinson disease, risk factors, prospective observation.

\section{Introduction}

Falls are one of the most incapacitating features of Parkinson disease (PD), and occur in 38-68\% of patients [1-4]. As many as $25 \%$ of patients have two or more falls over 6 months [4]. Koller et al. [5] reported that approximately $13 \%$ of patients experienced falls at least once a week. In a majority of cases, falling begins at moderately advanced stages of $\mathrm{PD}$, and as the disease progresses, the number of falls increases [6]. It was reported that falls can lead to an increased risk of mortality, morbidity and dependency in PD patients $[7,8]$. For this reason falling is a serious problem and identification of risk factors is crucial for their prevention.

The retrospective studies identified some factors associated with falls in PD patients, including older age, longer duration of disease, more severe postural instability, bradykinesia and rigidity, frequent episodes of freezing, and the presence of autonomic dysfunction $[9,10]$. To date, only a few prospective studies have considered the influence of selected factors on the risk of falls in PD [1,2,4,11-13], and their results are not unequivocal. According to these studies, the following factors contribute to an increased frequency of falls: older age $[11]$, longer duration of the disease $[2,11]$, greater severity of PD signs $[1,2,4,13,14]$, the predominance of bradykinesia and muscle rigidity in the clinical picture $[15,16]$, the postural instability and gait disturbance subtype of PD $[5,17,18]$, loss of arm swing [2], the presence of involuntary movements [19], coexisting dementia [2] and the presence of previous falls in the medical history [4]. In one study, polypharmacy and depression may also contribute to the occurrence of falls [1].

The aim of this study was to assess the incidence and risk factors for falls in a prospective study of patients with PD in comparison to healthy age-matched subjects. chorych na $\mathrm{ChP} \mathrm{i} \mathrm{7 \%} \mathrm{osób} \mathrm{z} \mathrm{grupy} \mathrm{kontrolnej.} \mathrm{U} \mathrm{często} \mathrm{upa-}$ dających w porównaniu z nieupadającymi stwierdzono większe nasilenie objawów w skalach UPDRS, S\&E, H\&Y, MMSE oraz w skali Hamiltona. Niezależnymi czynnikami ryzyka upadków były jednak: wiek, wcześniejsze raportowanie upadków oraz większa punktacja w FOG-Q.

Wnioski: Upadki występują trzykrotnie częściej u chorych na $\mathrm{ChP}$ w porównaniu z grupa kontrolna. Niezależnymi czynnikami ryzyka upadków są: wysoka punktacja w FOG-Q, starszy wiek oraz występowanie upadków w wywiadzie.

Słowa kluczowe: upadki, choroba Parkinsona, czynniki ryzyka, obserwacja prospektywna.

\section{Material and methods}

Participation in the study was offered to all consecutive PD patients visiting the Movement Disorders Clinic, Neurology Department, University Hospital in Krakow, between February 2004 and February 2005. Inclusion criteria were: diagnosis of PD according to UK PD Society Brain Bank criteria [20], disease duration of at least 3 years, Hoehn and Yahr stage II-IV, and sustained, longer than one year, good response to levodopa therapy.

Exclusion criteria were: severe gait disability with inability to walk unassisted, neurological, vascular or systemic disorders other than PD that might have caused permanent or intermittent weakness or instability, sever dementia, severe hepatic or renal insufficiency, cancer, a history of orthopaedic surgery of the hip or knee that had led to gait difficulties, other chronic disorders of the osteoarticular system leading to restricted mobility, and chronic disorders of the ear causing balance disturbances.

Age-matched ( \pm 2 years) controls were recruited from the persons accompanying the patient, excluding their caregivers, or others visiting in-patients of the Neurology Department. The exclusion criteria were the same as for patients, with the additional exclusion of any sign of parkinsonism in neurological examination.

The study protocol was approved by the local ethics committee and all participants gave their written informed consent to participate in this study.

The study was conducted in a prospective cross-sectional manner. All participants were interviewed by the same investigator (S.B.). In case of difficulties in carrying out an interview with the patient caused by cognitive impairment, the data about falls were collected from his caregivers. A fall was defined as an unexpected event 
during which the person inadvertently came to rest on the ground or other lower level [18].

During the first interview (at baseline), the patient and/or caregiver were asked about the number of falls occurring during the 12 months preceding the examination and gave anamnesis concerning PD and the neurological (confusion, dementia, depression, transient ischaemic attacks [TIA], etc.), cardiovascular, and other disorders potentially related to falls. Detailed questioning also included all drugs taken over the last 5 years. The interview was followed by a multidisciplinary assessment including: neurological, laryngological and ophthalmologic examination, electroencephalography (EEG), standard 12-lead electrocardiogram (ECG), ultrasonographic examination of the carotid and vertebral arteries, electronystagmographic evaluation of vestibular function, X-ray of the cervical spine and magnetic resonance imaging (MRI) of the brain to exclude other disease as the cause of falls (epilepsy, cardiogenic syncope, vestibular disease, TIA, vision disturbance, etc.), and evaluation of the cardiovascular system using a Biopac device [21]. The severity of the disease was assessed using the Unified Parkinson's Disease Rating Scale (UPDRS) (parts I-IV), the Hoehn and Yahr scale and the Schwab and England impairment of activities of daily living scale, cognitive dysfunction using the Mini Mental State Examination (MMSE) and depression using the Hamilton scale. Patients who experienced motor fluctuations were examined while in their 'on' state. Dyskinesias were assessed using the Goetz dyskinesia scale and episodes of freezing by means of the Freezing of Gait Questionnaire (FOG-Q), which consists of 6 subscales including the assessment of general gait difficulties (question 1 and 2), FOG frequency (question 3) and FOG severity (questions 4-6) [22].

Twelve months after the baseline assessment, patients were re-examined using the UPDRS, Hoehn and Yahr scale, Schwab and England scale, MMSE, Hamilton scale, Goetz dyskinesia scale and FOG-Q.

Data concerning the presence of chronic disease, balance and gait disturbances as well as any history of falls were collected also from the control group. Each member of the control group underwent a neurological examination. All participants (patients and controls) were obliged to report the occurrence and circumstances of each fall within 7 days following the event during the one-year follow-up in a special diary and/or by phone call. Patients were appointed to visit the clinic quarterly and encouraged to make an additional visit or immediate phone call in case of severe consequences of a fall, increased severity of PD symptoms and other medical events recognized as an emergency.

\section{Statistical analysis}

Categorical variables of patients and controls, and fallers and non-fallers were statistically assessed for association using the $\chi^{2}$ test and Fisher exact test. Normally distributed continuous variables were assessed using an independent samples $t$-test. The Mann-Whitney $U$-test was used for variables that were not normally distributed. In order to establish the risk factors for falls, logistic regression analysis was performed. Initially, several variables considered important for the occurrence of falls were included in a univariate analysis. The risk factors that were found to be significant in the univariate analysis were then included in a multivariate model in order to determine the odds ratios for variables independently associated with falls. A $p$-value $<0.05$ was considered statistically significant.

\section{Results}

One hundred out of the 106 patients with a diagnosis of idiopathic PD included in the study completed the 12-month follow-up. Of the six patients who dropped out of the study, three died, and three did not attend the follow-up visit. Fifty-six individuals were recruited to the control group. During follow-up, one person died and data from 55 controls were analysed.

Parkinson disease patients and the control group did not differ in terms of age (67.2 years vs. 65.5 years, $p=0.25$ ) or gender (women: $50.0 \%$ vs. $65.5 \%$, $p=0.065)$.

During the 12-month prospective observation, at least one fall occurred in $54(54 \%) \mathrm{PD}$ patients and in $10(18 \%)$ control subjects $(p=0.001)$. Thirty-four patients reported 1-3 falls, 6 patients had 4-5 falls, 5 patients reported 6-8 falls and 9 patients had more than 8 falls. The other three patients fell very frequently, from several to 20 times a day, making it difficult to accurately determine the number of falls. Excluding these patients, a total of 194 falls were reported by 51 patients. Of the 10 controls who reported falls, 5 individuals fell once or twice, 1 had 3 falls and 4 had 5 or more falls in a year.

In the year preceding the study, at least one fall occurred in $49(49 \%)$ patients and in $15(27 \%)$ controls $(p=0.006)$. Thirty-two patients reported 1-3 falls, 7 patients had 4-5 falls, 3 patients had 6-8 falls and 


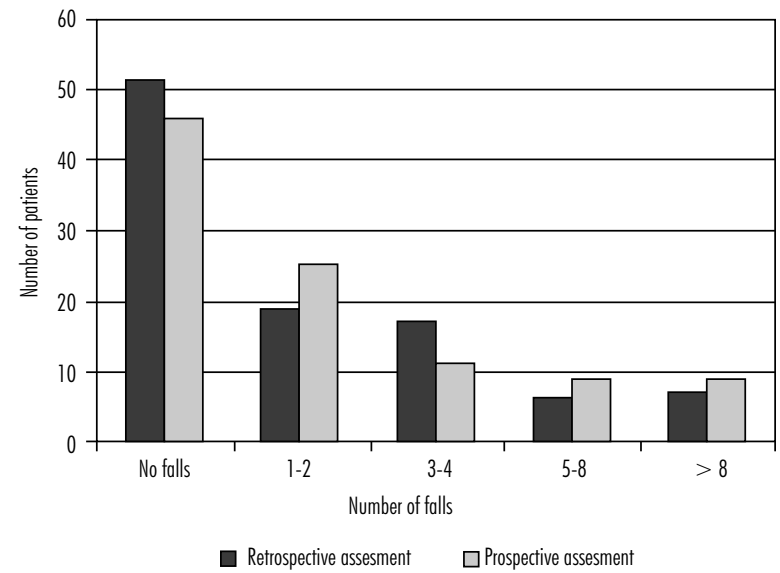

Fig. 1. Comparison of the number patients with falls in the year preceding the study (black) and during the prospective part of the study (grey)

7 patients had more than 8 falls. The incidence of falls reported in anamnesis (retrospective analysis) does not differ from prospective assessment $(p=0.887$ ) (Fig. 1).

Based on the number of falls occurring in the year preceding the study, patients were classified as non-fallers, rare fallers (1-3 falls in the past 12 months) and recurrent fallers (more than 3 falls). In prospective observation, falls did not occur in $66.7 \%$ of non-fallers, one to three falls were recorded in the majority of the remainder (31.3\%), and more than three falls in only $2 \%$ of patients. Of patients falling rarely in the previous year, $37.5 \%$ did not fall at all during the prospective observation, $34.4 \%$ remained rare fallers, and $28 \%$ of individuals fell more than three times. Of patients with a history of recurrent falls, $58.8 \%$ continued to have frequent falls, and the remaining $41.2 \%$ reduced their rate of falls to 1-3.

Comparison of patients who fell with non-fallers revealed that fallers were significantly older, had higher scores of total and part III and IV of UPDRS, lower score in MMSE, higher score on the Hamilton scale, as well as higher daily dose of levodopa. There were no significant differences in gender or duration of disease (Table 1).

Patients who, during the 1-year follow-up, began to fall (33 patients), or showed a significant increase in the occurrence of falls (28 patients), differed significantly from non-fallers with respect to the total UPDRS score, PD stage on the Hoehn and Yahr scale, and severity of disability according to the Schwab-England scale and the FOG-Q score, measured at the beginning and at the end of the study. They differed also in the severity of dyskinesia on the Goetz scale, the FOG-Q score, and the Hamilton scale score at the end of the study (Table 2).

Multivariate logistic regression analysis revealed that independent risk factors for falls in PD were: the occurrence of falls in the previous year $(\mathrm{OR}=1.79,95 \%$ CI: $1.28-3.84, p=0.0043)$, total score of FOG Questionnaire $(\mathrm{OR}=1.30,95 \% \mathrm{CI}: 1.08-1.56, p=0.0052)$ and age $(\mathrm{OR}=1.09,95 \% \mathrm{CI}: 1.00-1.19 ; p=0.0464)$, but not other factors included in this model such as gender, duration of disease, total UPDRS score, stage of

Table 1. Comparison between fallers and non-fallers

\begin{tabular}{|lcccc|}
\hline Characteristics & $\begin{array}{c}\text { All patients } \\
\text { [group 1] }\end{array}$ & $\begin{array}{c}\text { Fallers }(\boldsymbol{n}=\mathbf{5 4 )} \\
\text { [group 2] }\end{array}$ & $\begin{array}{c}\text { Non-fallers } \\
(\mathbf{n}=\mathbf{4 6}) \\
\text { [group 3] }\end{array}$ & $\begin{array}{c}P \text {-value } \\
\text { [group 2 vs. 3] }\end{array}$ \\
\hline Gender, (male/female) & $50 / 50$ & $29 / 25$ & $21 / 25$ & 0.423 \\
\hline Age [years]; mean $\pm \mathrm{SD}$ & $67.20 \pm 9.90$ & $69.85 \pm 9.20$ & $64.42 \pm 9.90$ & 0.005 \\
\hline PD duration [years]; mean $\pm \mathrm{SD}$ & $6.20 \pm 3.40$ & $6.77 \pm 3.80$ & $5.64 \pm 2.76$ & 0.095 \\
\hline UPDRS - part III total score; mean $\pm \mathrm{SD}$ & $32.20 \pm 13.80$ & $39.07 \pm 14.35$ & $30.07 \pm 12.70$ & 0.003 \\
\hline UPDRS - part IV total score; mean $\pm \mathrm{SD}$ & $3.53 \pm 3.40$ & $5.15 \pm 3.40$ & $3.00 \pm 3.10$ & 0.003 \\
\hline UPDRS total score; mean $\pm \mathrm{SD}$ & $48.90 \pm 13.70$ & $65.89 \pm 22.30$ & $46.24 \pm 19.00$ & 0.000 \\
\hline Hoehn and Yahr scale; mean $\pm \mathrm{SD}$ & $2.75 \pm 0.65$ & $2.97 \pm 0.63$ & $2.51 \pm 0.61$ & 0.000 \\
\hline Schwab and England scale; mean $\pm \mathrm{SD}$ & $79.93 \pm 13.70$ & $73.81 \pm 15.64$ & $86.17 \pm 7.68$ & 0.000 \\
\hline MMSE score; mean $\pm \mathrm{SD}$ & $27.46 \pm 3.50$ & $26.67 \pm 3.50$ & $28.31 \pm 2.02$ & 0.005 \\
\hline Hamilton scale; mean $\pm \mathrm{SD}$ & $9.10 \pm 6.15$ & $10.40 \pm 6.15$ & $7.67 \pm 6.29$ & 0.034 \\
\hline Levodopa daily dose [mg]; mean $\pm \mathrm{SD}$ & $736.6 \pm 336.8$ & $803.0 \pm 349.9$ & $659.3 \pm 306.9$ & 0.039 \\
\hline SD - standard deviation, PD - Parkinson disease, UPDRS - Unified Parkinson's Disease Rating Scale, MMSE-Mini-Mental Scale Examination &
\end{tabular}


Table 2. Comparison of patients who began to fall during the observation period, or had a higher number of falls than previously, and patients without falls

\begin{tabular}{|llccc|}
\hline Characteristics* & & \multicolumn{1}{c}{$\begin{array}{c}\text { Patients who began to fall } \\
\text { or fell with increasing frequency }\end{array}$} & Non-fallers & P-value \\
\hline Age [years] & 68.59 & 64.70 & 0.128 \\
\hline Duration of disease [years] & 6.59 & 5.74 & 0.264 \\
\hline Age of onset [years] & 62.00 & 59.02 & 0.258 \\
\hline Total UPDRS score & at baseline & 53.42 & 40.49 & 0.010 \\
\cline { 2 - 5 } & after 1 year & 65.22 & 46.97 & 0.001 \\
\hline Hoehn and Yahr scale & at baseline & 2.98 & 2.50 & 0.002 \\
\cline { 2 - 5 } & after 1 year & 3.05 & 2.64 & 0.018 \\
\hline Schwab and England scale & at baseline & 78.75 & 86.27 & 0.010 \\
\cline { 2 - 5 } & after 1 year & 76.19 & 84.25 & 0.001 \\
\hline Goetz dyskinesia scale & at baseline & 1.04 & 0.65 & 0.158 \\
\cline { 2 - 5 } & after 1 year & 1.50 & 0.65 & 0.006 \\
\hline FOG-Q & at baseline & 8.92 & 8.38 & 0.006 \\
\cline { 2 - 5 } & after 1 year & 13.53 & 28.11 & 0.005 \\
\hline MMSE & at baseline & 27.88 & 28.28 & 0.685 \\
\cline { 2 - 5 } & after 1 year & 27.08 & 7.86 & 0.151 \\
\hline Hamilton scale & at baseline & 10.03 & 0.183 \\
\cline { 2 - 5 } & after 1 year & 15.74 & 0.011 \\
\hline
\end{tabular}

*Data are presented as means.

disease on Hoehn and Yahr scale, Schwab and England score, MMSE, Hamilton scale, or part two of Goetz scale. Inclusion in the logistic regression model of additional factors, such as orthostatic hypotension, polypharmacy, or taking benzodiazepines, showed no evidence of their influence on the incidence of falls.

\section{Discussion}

The incidence of falls in PD patients (54\%) found in this prospective observation is in the range of previously reported incidences (38-68\%) studied in a prospective manner $[1,2,4,11,13,23,24]$. We also found a very similar percentage (49\%) of fall incidence in the year preceding the observation period reported in anamnesis by patients or their caregivers. The authors of prospective studies who took into account the history of falls reported similar results; $39-64 \%$ of their patients reported suffering falls in anamnesis $[1,2,4,9,13,23,24]$. This proves that a well-conducted interview concerning falls is a valuable research tool, despite some authors' concern over the reliability of such interviews. Thus, although retrospec- tive assessment clearly limits the ability to draw reliable conclusions as to the causes of and risk factors for falls, it correctly reflects the incidence of falls. Information about the occurrence of falls, even without details regarding their number and circumstances, has important prognostic significance - the presence of falls in the history is a risk factor for subsequent falls [25], as was also shown in this study. Likewise, a large percentage of patients without earlier falls will remain in this category. Similarly, those who have already fallen have a high chance of subsequent falls. However, approximately $30 \%$ of patients observed in this study deteriorated during a year. Falls occurred in patients who had not yet fallen or the number of falls increased so much that some rare fallers became frequent fallers during the 12-month follow-up.

Twenty percent of our PD patients (37\% of fallers) and $7.3 \%$ of controls fell more than 3 times a year (recurrent fallers). In other prospective studies, recurrent falls were reported in $24-50 \%$ of patients $[2,4,13]$. The varying proportions of patients with recurrent falls may reflect the different definitions adopted by researchers. Some authors define recurrent falls as those that occur 
with a frequency of at least two per year [2], whereas others require at least two within 6 months [4]. We defined recurrent falls as more than three falls in a year. In our opinion, one, two or even three falls can occur accidentally, but PD patients who fall four times a year are considered at risk of falls that occur not by chance but as a result of disease. The risk of complications increases with recurrent falls, so it is essential to distinguish patients with a "tendency" for frequent or recurrent falls.

In this study, a history of previous falls, total score of the FOG-Q and age were identified as independent risk factors for subsequent falls. These results are consistent with previously published studies. A meta-analysis of prospective studies on falls in PD revealed that the strongest risk factor for falls is the presence of two or more falls in the previous year (sensitivity $68 \%$, specificity $81 \%$ ) [25]. The same conclusions were published by other authors $[2,4,24]$. A similar result was obtained in another meta-analysis of studies concerning falls in the elderly population [26]. This indicates that it is essential to collect information on earlier falls in a parkinsonian patient. In the clinical setting, we can use this information to predict, with high probability, whether a patient is at risk of falls in the next year.

Older age as a risk factor of falls has been reported previously in both PD patients [3,5] and the general elderly population [27]. The duration of PD increases with age, along with the probability of worsening symptoms and the number and severity of coexisting illnesses and, as a result, medicine consumption may increase. Many of these related elements did not reach, however, statistical significance as independent risk factors in this study.

Another statistically significant risk factor of a fall in this study was the severity of freezing episodes assessed using the FOG-Q score. Kerr et al. [13] also found a higher score in this questionnaire to be a predictor of falls. The FOG-Q, which was developed and validated by Giladi et al. [22], has proved a useful tool with which to assess the severity of gait disturbance and freezing episodes, giving much more information than the prevalence of episodes by itself, as in the case of the $10^{\text {th }}$ subsection in part II of the UPDRS. Individuals who had begun to fall, or experienced a significant increase in falls during the 1-year follow-up, also had a significantly higher score in the FOG-Q than non-fallers, at both the beginning and end of the study.

Our study does not confirm previously published data indicating that the duration of disease $[2,9,28]$, lat- er age of PD onset [8], the severity of the disease measured by the Hoehn and Yahr scale or UPDRS [1,2, $9,27]$, cognitive dysfunction [2], and the presence of symptomatic orthostatic hypotension [13] are risk factors for falls in PD patients.

The absolute duration of the disease and later age of onset may be, but are not necessarily, risk factors for falls. On the one hand, the longer the disease lasts or the more advanced the age of the patient is, the more likely it is that there will be more new factors that have an adverse effect on locomotion (e.g., vision impairment, memory impairment, cardiovascular diseases). On the other hand, the presence of falls also depends on the form of the disease. Falls occur more frequently in postural instability and gait difficulty dominant PD (PIGD-PD) than in tremor dominant PD (TD-PD) $[5,17,18]$. As a consequence, the importance of disease duration or later age of onset as a risk factor decreases.

The severity of disease assessed using the UPDRS, Hoehn and Yahr and Schwab and England scales was not an independent risk factor for falls in this study. Many controversial data concerning the severity of parkinsonian symptoms as a predictor of falls have been published. Pickering et al. [25] reported that a higher total score in the UPDRS, as well as a more advanced stage on the Hoehn and Yahr scale, was predictive of falls. A higher score in the UPDRS was also a risk factor for falls in several other studies $[13,29]$. On the other hand, Wood et al. [2] found no evidence that the UPDRS score is an independent risk factor for falls. However, in this study we found a higher severity of disease in fallers in comparison to non-fallers, assessed by means of the above-mentioned scales and confirmed by previously published studies $[2,13]$.

In our study, patients with falls had a significantly lower score in the MMSE compared to non-fallers, but multivariate regression analysis showed no evidence that a lower score on this scale was a risk factor for falls. Previous publications concluded the opposite: in the paper by Robinson et al. [28], patients with and without falls did not differ in the MMSE score, while in the study by Wood et al. [2], cognitive impairment was a predictor of falls in PD. A patient with impaired cognitive function can be inattentive, uncritical, and his/her behaviour can be risky, thus predisposing to a fall. The need to care for such patients and the constant presence of third parties may reduce the risk of falling. A patient without memory problems is more mobile and independent but is also more exposed to environmental factors. 


\section{Acknowledgements}

This study was supported with a grant received from the State Committee of Research (grant no. 3PO5B. 020.25).

\section{Disclosure}

Authors report no conflict of interest.

\section{References}

1. Ashburn A., Fazakarley L., Ballinger C., et al. A randomised controlled trial of a home based exercise program to reduce risk of falling among people with Parkinson's disease. J Neurol Neurosurg Psychiatry 2007; 78: 678-684.

2. Wood B.H., Bilclough J.A., Bowron A., et al. Incidence and prediction of falls in Parkinson's disease: a prospective multidisciplinary study. J Neurol Neurosurg Psychiatry 2002; 72: 721-725.

3. Wieliński C.L., Erickson-Davis C., Wichmann R. Falls and injuries resulting from falls among patients with Parkinson's disease and other parkinsonian syndromes. Mov Disord 2005; 20: 410-415.

4. Bloem B.R., Grimbergen Y., Cramer M., et al. Prospective as sessment of falls in Parkinson's disease. J Neurol 2001; 248: 950-958.

5. Koller W.C., Glatt S., Vetere-Overfield B., et al. Falls and Parkinson's disease. Clin Neuropharmacol 1989; 12: 98-105.

6. Hely M.A., Morris J.G., Reid W.G., et al. Sydney Multicenter Study of Parkinson's disease: non-L-dopa-responsive problems dominate at 15 years. Mov Disord 2005; 20: 190-199.

7. Ebmeier K.P., Calder S.A., Crawford J.R., et al. Mortality and causes of death in idiopathic Parkinson's disease: results from the Aberdeen whole population study. Scott Med J 1990; 35: 173-175.

8. Bennett D.A., Beckett L.A., Murray A.M., et al. Prevalence of parkinsonian signs and associated mortality in a community population of older people. $N$ Engl J Med 1996; 334: 71-76.

9. Balash Y., Peretz C., Leibovich G., et al. Falls in outpatients with Parkinson's disease. Frequency, impact and identifying factors. J Neurol 2005; 252: 1310-1315.

10. Williams D.R., Watt H.C., Lees A.J. Predictors of falls and fractures in bradykinetic rigid syndromes: a retrospective study. J Neurol Neurosurg Psychiatry 2006; 77: 468-473.

11. Gray P., Hildebrand K. Fall risk factors in Parkinson's disease. J Neurosci Nurs 2000; 32: 222-228.

12. Kerr G.K., Worringham C., Silburn P. Sensimotor and clinical factors in the prediction of future falls in Parkinson's disease. Proceedings of the IXth Congress o the International Society for Postural and Gait Research, 2003.

13. Kerr G.K., Worringham C.J., Cole M.H., et al. Predictors of future falls in Parkinson's disease. Neurology 2010; 75: 107-108.

14. Matinolli M., Korpelainen J.T., Sotaniemi K.A., et al. Recurrent falls and mortality in Parkinson's disease: a prospective twoyear follow-up study. Acta Neurol Scand 2011; 123: 193-200.
15. Michałowska M., Krygowska-Wajs A., Jedynecka U., et al. Analysis of causes for falls in people with Parkinson's disease. Neurol Neurochir Pol 2002; 36: 57-68.

16. Kemoun G., Defebre L. Gait disorders in Parkinson's disease. Gait freezing and falls: therapeutic management. Presse Med 2001; 30: 460-468.

17. Jankovic J., McDermott M., Carter J. Variable expression of Parkinson's disease: a base-line analysis of the DATATOP cohort. Neurology 1990; 40: 1529-1534

18. Rudzińska M., Marona M., Bukowczan S., et al. Falls in different types of Parkinson's disease. Neurol Neurochir Pol 2007; 41: 395-403.

19. Albanese A. Can falls be prevent in Parkinson's disease? J Neurol Neurosurg Psychiatry 2007; 78: 661.

20. Litvan I., Bhatia K.P., Burn D.J., et al. Movement Disorders Society Scientific Issues Committee report: SIC Task Force appraisal of clinical diagnostic criteria for Parkinsonian disorders. Mov Disord 2003; 18: 467-486.

21. Czarkowska H., Tutaj M., Rudzińska M., et al. Cardiac responses to orthostatic stress deteriorate in Parkinson disease patients who begin to fall. Neurol Neurochir Pol 2010; 44: 339-349.

22. Giladi N., Shabtai H., Simon E.S. Construction of freezing of gait questionnaire for patients with Parkinson's disease. Parkinsonism Relat Disord 2000; 55: 411-412.

23. Bloem B.R., Munneke M., Mazibrada G. The nature of falling in progressive supranuclear palsy. Mov Disord 2004; 19: 359360.

24. Ashburn A., Stack E., Pickering R.M., et al. Predicting fallers in a community-based sample of people with Parkinson's disease. Gerontology 2001; 47: 277-281.

25. Pickering R.M., Grimbergen Y.A., Rigney U., et al. A metaanalysis of six prospective studies of falling in Parkinson's disease. Mov Disord 2007; 22: 1892-1900.

26. Deandrea S., Lucenteforte E., Bravi F., et al. Risk factors for falls in community-dwelling older people: a systematic review and meta-analysis. Epidemiology 2010; 21: 658-668.

27. Cryer C., Patel S. Falls, fragility and fractures. National Service Framework for older people: The case for and strategies to implement a joint Health Improvement and Modernisation Plan for Falls and Osteoporosis. November 2001.

28. Robinson K., Dennison A., Roalf D., et al. Risk factors falling in Parkinson's disease. NeuroRehabilitation 2005; 20: 169-182.

29. Mak M.K., Pang M.Y. Fear of falling is independently associated with recurrent falls in patients with Parkinson's disease: a 1-year prospective study. $J$ Neurol 2009; 256: 1689-1695. 